\title{
KECERDASAN EMOSIONAL DAN PRESTASI KERJA PADA \\ DISTRIBUTOR MULTI LEVEL MARKETING (MLM) K-LINKCABANG SIDOARJO
}

\author{
Ririn Dewanti Dian S. I., Merah Purnama Sari \\ Fakultas Psikologi Universitas Muhammadiyah Sidoarjo
}

\begin{abstract}
Employee performance is very influential to the success of a company, especially a company based in the field of multi-level marketing (MLM) in which a person in demand hard to be able to use their emotional intelligence in order to get satisfactory results for their customers. The purpose of this study to determine the relationship of emotional intelligence with performance on the distributor of multi level marketing (MLM). This study used a quantitative approach. The variables of this study was emotional intelligence as an independent variable (X) and the interpretation of the work as the dependent variable (Y). The Sampling techniques was 100distributors through proposive sampling based on predetermined criteria. Process analysis using Pearson product moment correlation analysis performed using SPSS-17 For Windouws. Results of correlation (Pearson correlation) obtained $=0689$ and $\mathrm{p}<0.05(0.000<0.05)$, which means that there was a relationship of emotional intelligence with work performance distributors of Multi Level Marketing.
\end{abstract}

Key words: Employee performance, a success of a company

\begin{abstract}
ABSTRAK
Prestasi kerja karyawan sangatlah berpengaruh terhadap kesuksesan sebuah perusahaan, apa lagi bagi perusahaan yang berbasis di bidang multi level marketing (MLM) dimana seseorang di tuntut keras untuk dapat menggunakan kecerdasan emosinya agar dapat mendapatkan hasil yang memuaskan bagi para kastamer mereka. Tujuan penelitian ini untuk mengetahui adanya hubungan kecerdasan emosi dengan prestasi kerja pada distributor multi level marketing (MLM). Penelitian ini menggunakan pendekatan kuantitatif. Variabel penelitian ini adalah kecerdasan emosi sebagai variabel independen (X) dan pretasi kerja sebagai variabel dependen (Y). Teknik sampling menggunakan proposive sampling sebanyak 100 distributor dengan kreteria yang telah ditentukan. Proses analisisnya mengunakan analisis korelasi product moment pearson dilakukan dengan menggunakan program SPSS-17 For Windouws. Hasil uji korelasi (pearson correlation) diperoleh $=0.689$ serta nilai $\mathrm{p}<0,05(0,000<0,05)$ yang berarti bahwa ada hubungan kecerdasan emosional dengan prestasi kerja distributor Multi Level Marketing
\end{abstract}

Kata Kunci: Prestasi kerja karyawan, kesuksesan perusahaan.

\section{PENDAHULUAN}

Bisnis Multi Level Marekting (MLM) sekarang menjadi terobosan baru di Negara Indonesia, hal ini bisa dilihat dari banyaknya perusahaan Multi Level Marekting (MLM) yang ada di Indonesia dan banyaknya orang yang berminat untuk bergabung dalam program-program yang ditawarkan oleh perusahaan tersebut. Multi Level Marekting (MLM) adalah salah satu strategi pemasaran, dengan membangun saluran distribusi, untuk menyalurkan barang dari produsen sampai ke konsumen atau pemakai industri disebut dengan saluran distribusi (Warren J. Keegan 2003). 
Multi Level Marekting (MLM) di tinjau dari segi kata terdiri dari Multi Level dan Marketing, Multi yang artinya banyak, Level berarti berjenjang atau tingkat, sedangkan Marketing berarti pemasaran. Marketing dalam pengertiannya mencakup beberapa aspek antara lain produk, harga, distribusi dan promosi, sedangkan Multi Level dalam pengertiannya menyangkut peran organisasi distributor secara berjenjang atau bertingkat. Seorang distributor yang sudah bergabung, maka distributor tersebut dapat mengajak orang lain untuk turut serta sebagai distributor. Kemudian orang tersebut dapat pula mengajak orang lain untuk ikut bergabung, begitu seterusnya. Semua orang yang diajak dan ikut bergabung merupakan suatu kelompok distributor. Mengajak orang untuk ikut bergabung dalam bisnis Multi Level Marketing (MLM) tersebut tidak terbatas, sampai berapa tingkat atau sampai berapa level pun bebas tanpa dibatasi. http://www.masbied.com

Multi Level Marketing (MLM) dalam Wikipedia (ensklopedia bebas) bahasa Indonesia diartikan sebagai sistem penjualan yang memanfaatkan konsumen sekaligus sebagai tenaga penyalur (distributor) secara langsung. Menurut David Roller (1995) Multi Level Marketing adalah system melalui sebuah induk perusahaan yang mendistribusikan barang atau jasanya lewat jaringan orang-orang bisnis yang independen, orang-orang bisnis tersebut kemudian mensponsori orang-orang lain lagi untuk membantu mendistribusikan barang atau jasa tersebut.
Perseroan Terbatas (PT) K-Link merupakan salah satu perusahaan Multi Level Marekting (MLM) yang berkembang di Indonesia sejak tahun 2003 sampai sekarang. Selain membawa tradisi pengetahuan tentang kasih sayang dan prikemanusiaan dalam bentuk support system dalam bisnis multilevel ini, KLink juga mempunyai tujuan dalam menjalankan bisnis ini yaitu untuk membantu para distributor untuk meraih prestasi kerjanya.

Robert Tampubolon (2004) dalam bukunya mengatakan bahwa profesi paling bergengsi adalah profesi menjual, alasannya karena profesi menjual bukanlah milik semua orang, karena tidak semua orang secara sadar mau atau berani menyatakan dirinya sebagai penjual, sedangkan profesi menjual adalah profesi yang halal. Menjual dalam bisnis Multi Level Marekting (MLM) bukan saja untuk mendapatkkan keuntungan langsung tetapi lebih dari itu. Menjual berarti menyebarkan informasi tentang produk. Dengan menjual berarti semakin banyak orang yang mengenal produk, sehingga orang-orang yang sudah mengenal produk tersebut pada akhirnyaakan diajak untuk ikut bergabung menjalankan bisnis Multi Level Marekting (MLM) ini.

Pertengahan tahun 2011 perkembangan bisnis Multi Level Marekting (MLM) K-Link di kawasan Sidoarjo jumlah omset dan juga jumlah member baru yang masuk $\pm 50 \%$ mengalami penurunan di bandingkan tahun-tahun 20032010. Penurunan tersebut disebabkan karena munculnya persaingan bisnis Multi Level Marekting (MLM) lain 
yang ada di kawasan Sidoarjo, sehingga mengakibatkan banyak distributor-distributor yang pindah ke dalam bisnis Multi Level Marekting (MLM) lain. Efek dari persaingan tersebut beberapa distributor melakukan tindakan-tindakan curang dalam masalah penjualan produk kepada konsumen dengan harga yang tidak sesuai dengan perusahaan, sehingga menyebabkan jaringanjaringan kerja (downline) mereka melemah, semakin tidak aktif dalam support system, omset yangdiperoleh juga mengalami banyak penurunan.

Distributor K-Link yang sebelumnya aktif sekarang menjadi pasif, baik dari segi penjualan maupun rekruitmen downline baru. Dari data yang ada di Sub Stockist Sidoarjo pada tahun 2008-2010 jumlah aplikasi baru (member baru) yang masuk \pm 85 orang setiap bulannya dan omset penjualannya 30.000 point setiap bulannya, sedangkan untuk tahun 2011- 2012 kondisi K-Link mengalami penurunan member baru yang masuk setiap bulannya \pm 25 orang dan omset penjualannya 12.000 point per bulan.

Melakukan proses perekrutan atau dalam bahasa MLMnya disebut sebagai prospecting yang ada kaitannya dengan bisnis Multi Level Marekting (MLM) berarti mengajak seseorang untuk bergabung menjalankan bisnis yang ditawarkan, baik itu orang yang sudah dikenal dengan baik maupun orang yang baru dikenal dan bahkan yang belum dikenal sekalipun. Prospecting atau proses perekrutan dalam bisnis Multi Level Marekting (MLM) sangat menentukan kesuksesan prestasi kerja seseorang yang menjalankannya, sebab bila tidak terjadi proses perekrutan dalam jaringan bisnisnya maka kondisi omsetnya akan melemah. Hal ini berkaitan erat dengan penjualan atau selling, penjualan yang dilakukan oleh satu orang meskipun mampu menjual sebanyak-banyaknya sudah pasti tidak akan sebanyak kalau dijual oleh banyak orang.

Dari fakta yang ada, untuk meningkatkan kondisi di tengah persaingan yang ketat sangat diperlukan Sumber Daya Manusia (SDM) atau seorang distributor yang berkualitas sehingga mampu menghadapi persaingan dan perubahan yang nantinya akan terjadi pada perusahaan. Lingkungan yang sekarang dihadapi oleh Sumber Daya Manusia (SDM) sangat menantang karena perubahan yang muncul sangat cepat dan memiliki masalah yang luas (Mathis, 2001).

Distributor yang bekerja secara profesional selalu merasa bahwa waktu adalah kesempatan yang menjadikan tolak ukur dalam pencapain prestasi kerjanya. Suatu hal yang sia-sia jika sebagai individu atau distributor, selama mengikuti bisnis Multi Level Marekting (MLM) ini pencapaian prestasinya tidak mengalami peningkatan dari tahun ke tahun, sedangkan di lihat secara global bisnis Multi Level Marekting (MLM) K-Link di Indonesia masih memiliki pasar yang luas untuk bisa dikembangkan, tinggal melihat kemampuan distributor dalam menjalankan bisnis tersebut dengan baik.

Menurut Hasibuan (2002) prestasi kerja adalah suatu hasil kerja yang dicapai seseorang dalam 
melaksanakan tugas yang dibebankan kepadanya, yang didasarkan atas kecakapan, pengalaman dan kesungguhan. Untuk meningkatkan prestasi kerja perlu diperhatikan faktor-faktor yang mempengaruhinya adalah faktor kemampuan dan faktor motivasi. Secara psikologis, kemampuan (ability) terdiri dari kemampuan potensi (IQ) dan kemampuan reality (knowledge + skill) sedangkan untuk motivasi terbentuk dari sikap (atitude) seorang karyawan dalam menghadapi situasi kerja. Motivasi merupakan kondisi menggerakkan diri individu yang terarah untuk mencapai tujuan organisasi atau tujuan kerja (Mangkunegara,2000).

Menurut Multi Level Marketing (MLM) K-Link prestasi kerja distributor adalah hasil kerja yang dilakukan dalam melakukan pembelian, penjualan dan merekrut anggota baru untuk menunjang keberhasilan dalam meraih prestasi kerja yang maksimal dengan kurun waktu yang sudah ditentukan oleh perusahaan. Bisnis jaringan adalah sebuah bisnis yang memiliki potensi pendapatan yang sangat besar, bahkan bisa dikatan tidak terbatas. Hal ini dikarenakan dalam jaringan, seseorang tidak dibatasi untuk mendapat rekan kerja atau anggota baru dalam menjalankan bisnis multi level tersebut.

Prestasi kerja dalam bisnis Multi Level K-Link hasil pembelian dan hasil penjualan serta rekruitmen anggota baru dijadikan sebagai alat ukur untuk mencapai prestasi kerja. Pada pekerjaan-pekerjaan tertentu, sifat-sifat kepribadian seseorang sangat mempengaruhi prestasi kerja yang dihasilkannya. Menurut Goleman (1996) untuk memiliki prestasi kerja yang menonjol hanya disyaratkan kecakapan emosi tertentu. Pekerjaan berbeda memerlukan kecakapan emosi yang berbeda pula, bisnis multilevel ini mengharuskan seorang distributor setiap harinya bertemu dengan banyak orang dengan karakter yang berbeda-beda, dan setiap karakter membutuhkan penanganan yang berbeda pula, untuk dapat mengetahui dan menangani emosional orang lain secara tepat maka diperlukan kecerdasan emosional yang tinggi.

Menurut Goleman ada lima aspek dalam kecerdasan empsional yaitu:

a. Mengenali emosi diri

Mengenali emosi diri adalah kemampuan merasakan emosi tepat pada waktunya dan kemampuan dalam memahami kecenderungan dalam situasi tersebut. Kesadaran diri menyetakan kemampuan seseorang menguasai reaksi pada berbagai peristiwa, tantangan, bahkan orang-orang tertentu

b. Mengelola emosi

Mengelolah emosi berarti memahaminya, lalu menggunakan pemahan tersebut untuk menghadapi situasi secara produktif; bukannya menekan emosi dan menghilangkan informasi berharga yang di sampaikan oleh emosi kepada diri sendiri

c. Memotivasi diri sendiri

Motivasi diri sendiri adalah daya pendorong yang mengakibat- 
kan seseorang anggota organisasi mau dan rela untuk mengerahkan kemampuan dalam bentuk keahlian dan ketrampilan tenaga dan waktunya untuk menyelenggarakan berbagai kegiatan yang menjadi tanggung jawabnya dan menunaikan kewajibannya, dalam rangka pencapaian tujuan dan berbagai sasaran organisasi yang telah ditentukan sebelumnya

d. Mengenali emosi orang lain (empati)

Mengenal emosi orang lain merupakan kecerdasan terhadap perasaan, kebutuhan, dan kepentingan orang lain. Pada tingkat yang paling rendah, empati mempersyaratkan kemampuan membaca emosi orang lain, pada tataran yang lebih tinggi, empati mengharuskan kita mengindra dan menanggapi kebutuhan atau perasaan seseorang yang tidak diungkapkan lewat kata-kata

e. Memilikiketrampilan sosial

Kemampuan berkomunikasi secara efektif merupakan hal yang sangat penting bagi kecerdasan emosional, dan tidak terukur nilainya di dalam kehidupan. Keterampilan sosial merupakan aspek penting dalam Emosional Intelligence. Ketrampilan sosial bisa diperoleh dengan banyak berlatih. Salah satu kunci keterampilan sosial adalah seberapa baik atau buruk seseorang mengungkapkan perasaannya sendiri. Oleh sebab itu, untuk dapat menguasai keterampilan untuk berhubungan dengan orang lain (keterampilan sosial) dibutuhkan kematangan dua ketrampilan emosional yang lain, yaitu pengendalian diri dan empati. Tanpa memiliki keterampilan, seseorang akan mengalami kesulitan dalam pergaulan sosial.

Penelitian Goleman menunjukkan bahwa kecerdasan emosional ini adalah kemampuan yang sangat dibutuhkan dalam dunia kerja saat ini, yaitu sekitar 75-94 persen, sedangkan peran IQ (Intelligence Quotient) atau keterampilan dalam keberhasilan di dunia kerjanya menempati posisi kedua sesudah kecerdasan emosional dalam menentukan peraihan prestasi puncak dalam pekerjaan yaitu sekitar 4-25\% (Goleman, 1996). Menurut Goleman, khusus pada orang-orang yang murni hanya memiliki kecerdasan akademis tinggi, mereka cenderung memiliki rasa gelisah yang tidak beralasan dan cenderung sulit mengekspresikan kekesalan dan kemarahannya secara tepat. Karena sifat-sifat demikian, bila seseorang memiliki IQ tinggi namun taraf kecerdasan emosionalnya rendah maka cenderung akan terlihat sebagai orang yang keras kepala dan mudah putus asa.

Hasil beberapa penelitian di University of Vermont mengenai analisis struktur neurologis otak manusia dan penelitian perilaku oleh LeDoux (1970), menunjukkan bahwa dalam peristiwa penting kehidupan seseorang, Emotional Question (EQ) selalu mendahului intelegensi rasional. Emotional Question (EQ) yang baik dapat menentukan keberhasilan individu dalam prestasi kerja membangun kesuksesan karier, mengembangkan hubungan suamiistri yang harmonis dan dapat mengurangi agresivitas (Goleman, 
2002). Nisak (2010) juga meneliti tentang hubungan kecerdasan emosional dengan kinerja guru SDI SABILIL HUDA somorame, menunjukkan adanya hubungan yang signifikan antara hubungan kecerdasan emosional dengan kinerja guru dengan koefisien korelasi 0,647. Nilai koefisien korelasi tersebut positif, yang artinya semakin tinggi kecerdasan emsional guru, maka semakin tinggi pula kinerja guru, dan sebaliknya semakin rendah kecerdasan emosional guru, maka semakin rendah pula kinerja guru.

Kecerdasan emosional bekerja secara sinergi dengan keterampilan kognitif, orang-orang berprestasi memiliki keduanya. Tanpa kecerdasan emosional, orang tidak akan bisa menggunakan kemampuankemampuan kognitif mereka sesuai dengan potensi yang maksimal. Kecerdasan emosional tersebut akan mempengaruhi perilaku tiap individu dalam mengatasi permasalahan yang muncul pada diri orang tersebut, termasuk dalam permasalahan kerja.

Berdasarkan uraian diatas, peneliti perlu mengadakan penelitian berkenaan problematika yang telah dibahas diatas .Tujuan penelitian ini adalah untuk mengetahui dan mendapatkan bukti empiris tentang adanya hubungan antara kecerdasan emosional dengan prestasi kerja distributor Multi Level Marketing (MLM) K-Link yang ada di cabang Sidoarjo.

\section{BAHAN DAN METODE}

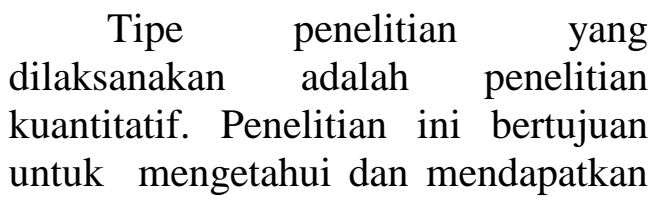

data empiris adanya hubungan sebuah korelasi (Merah. 2012). Pada penelitian ini, peneliti ingin mengetahui hubungan antara kecerdasan emosional sebagai variabel independen (X) dengan prestasi kerja sebagi variabel dependen (Y) di distributor Multi Level Marketing (MLM) K-Link cabang Sidoarjo.

ini, $\begin{array}{cc}\text { Pendekatan dalam } & \text { penelitian } \\ \text { menggunakan } & \text { penelitian }\end{array}$ kuantitatif korelatif yang akan menguji hipotesis yang mengandung pernyataan hubungan pada variabel terikat yang dipengaruhi keberadaan variabel bebas. Penelitian kuantitatif menekankan analisisnya pada datadata numerikal (angka) yang diolah dengan metode stastistika (Azwar 2007).

Teknik statistik yang digunakan dalam perhitungan hasil data yang telah terkumpul diolah dan dianalisa menggunakan teknik Korelasi Product Moment dari Karl Pearson dengan pertimbangan bahwa menurut Sugiyono (2003) untuk menguji hipotesis asosiatif/hubungan bila datanya berbentuk interval atau rasio dengan satu variabel independen dan satu variabel dependen.

Sebelum dilakukan pengujian hubungan dengan menggunakan teknik Korelasi Product Moment, pertama kali yang perlu dilakukan ialah untuk uji asumsi, Asumsi dapat diartikan sebagai anggapan, jadi dalam menerapkan suatu model statistik tertentu untuk menguji data para peneliti mendasarkan diri pada anggapan-anggapan tertentu (Hadi, 2000). Uji asumsi itu sendiri terdiri dari : uji normalitas data dan uji linearitas sampel. Pedoman yang 
digunakan untuk normal tidaknya sebaran adalah jika $\mathrm{p}>0.05$ maka data dikatakan normal, sedangkan apabila $\mathrm{p}<0.05$ maka data dikatakan tidak normal (Azwar, 2008). Untuk menguji Normalitas Skala kecerdasan emosional digunakan Teknik Kolmogorov-Smirnov. Sedangkan Pemeriksaan kelinieran regresi dilakukan melalui pengujian hipotesis nol, bahwa regresi linier melawan hipotesis tandingan yakni regresi tidak linier (Ali muhidin dan Abdurrahman, 2009). Perhitungan analisa data dilaksanakan dengan menggunakan program SPSS versi 17.00 for windows.

Subyek dalam penelitian ini adalah distributor yang masih aktif dalam pembelanjaan produk K-Link mulai tahun 2009-2011 dengan batas pembelanjaaan minimal 100 point selama satu bulan. Jumlah distributor seanyak 100 yang dipilih dengan menggunakan metode purposive sampling yang memilih sekelompok subyek berdasarkan atas ciri-ciri atau sifat-sifat tertentu yaitu :

1) Distributor K-Link yang sudah bergabung periode tahun 20092011

2) Dalam satu tahun mencapai level menejer minimal 243 downline

3) Distributor yang masih aktif dalam pembelanjaan dengan omset point minimal 100 point maksimal 400 point setiap bulan.

4) Bersedia memberikan informasi dan mengisi skala

Pada penelitian ini variabel prestasi kerja diukur menggunakan alat ukur berdasarkan omset point pembelian dan banyaknya jumlah downline yang sudah ditetapkan oleh perusahaan Multi Level Marketing
(MLM) K-Link Omset point diperoleh dari hasil pembelian produk setiap bulannya dengan batas minimal 100 point Rp. 500.000 dan maksimal 400 point Rp. 2.000.000 setiap bulannya, jumlah downline yang berhasil di rekrut oleh level menejer minimal 243 distributor, sedangkan variabel kecerdasan emosionaldiukur menggunakankecerdasan emosional berdasarkan indikator kecerdasan emosional pada aspek kesadaran diri, pengaturan diri, memotivasi diri sendiri, mengenali emosi orang lain, dan membina hubungan dengan orang lain.

Skala kecerdasan emosi dikembangkan dengan model skala Likert yang menggunakan lima pilihan jawaban yaitu sangat setuju, setuju, tidak dapat menentukan (netral), tidak setuju, dan sangat tidak setuju pada item favourabel dan item unfavourabel. Masing-masing kategori jawaban mempunyai rating yang bergerak dari satu hingga lima.

Skala kecerdasan emosi terdiri dari 40 item dan dilakukan uji validitas yaitu dengan mencari kesahihan aitem dengan melihat daya diskriminasi aitem. Teknik ini melakukan korelasi antara distribusi skor tes yang bersangkutan dengan distribusi skor kriteria yang relevan, yaitu distribusi skor skala, dengan korelasi tersebut dihasilkan koefisien korelasi. Setelah mendapatkan hasil, maka dapat dilihat aitem-aitem mana saja yang signifikan (dapat digunakan), serta aitem-aitem mana saja yang gugur, yang ditentukan dengan membandingkan nilai korelasi perhitungan dengan nilai probabilitas sesuai dengan level of significancy sebesar 0,30 menurut Azwar (1999). 
Berdasarkan hal tersebut maka dapat ditentukan jumlah aitem yang lolos seleksi aitem, yaitu : Skala kecerdasan emosional yaitu dari hasil perhitungan yang dilakukan dengan bantuan program SPSS 17.0 for Windows, untuk kecerdasan dari 40 aitem didapat 17 aitem yang layak untuk digunakan pada penelitian

Setelah melakukan uji validitas, pengukuran reliabilitas alat ukur dilakukan dengan teknik sekali ukur, yaitu dengan pendekatan konsistensi internal. Pendekatan ini dilakukan dengan menggunakan satu bentuk tes yang dikenakan hanya sekali saja pada sekelompok subjek (single trial administration). Hasil Uji reliabilitas Skala kecerdasan emosional dilakukan dengan reliabilitas Alpha Cronbach dengan bantuan SPSS 17 sebanyak dua kali dan dihasilkan nilai reliabilitas sebesar 0,843 dengan jumlah total 17 item. Menurut Azwar (1999) bahwa reliabilitas di atas 0,8 adalah baik, maka dapat dinyatakan bahwa skala kecerdasan emosional adalah reliabel.

Pelaksanaan penelitian ini dimulai pada tanggal tanggal 2 Juli 23 Juli 2012 di Sub Stockist Sidoarjo. Jumlah distributor yang dijadikan sampel penelitian adalah sebanyak 100 menejer sesuai dengan data stockist. Selama 18 hari jumlah koesioner yang terkumpul di Sub stockiest Sidoarjo sebanyak 70 responden. Untuk mendapatkan 30 responden peneliti melakukan penyebaran angket di Stockist Center Sidoarjo selama 2 hari mulai tanggal 23 juli-24 juli 2012. Peneliti mengalami sedikit kesulitan dalam mencari responden, sehingga peneliti harus menyebarkan skalanya di
Stockist Center Sidoarjo untuk mendaptkan semua responden. Dari data 100 responden tersebut akan di lanjutkan oleh peneliti dalam tahap pengolahan data.

Setelah data terkumpul, peneliti melakukan tahap penyelesaian antara lain: Editing yaitu kegiatan dimana peneliti memeriksa kejelasan dan kelengkapan pengisian instrumen pengumpulan data, Skoring yaitu kegiatan memberikan skor pada tiap jawaban atas pernyataan yang diberikan oleh subyek, Coding yaitu kegiatan mengidentifikasi dan mengklasifikasi dari setiap pernyataan yang terdapat dalam instrumen pengumpulan data menurut variabel-variabel yang diteliti, dan yang terakhir Tabulating yaitu kegiatan mencatat atau entri data ke dalam tabel induk peneltitian. Untuk hasil tabulating yang sudah dilakukan oleh peneliti bisa dilihat pada halaman lampiran hasil tabulasi data.

\section{HASILDAN PEMBAHASAN}

Menguji data penelitiannya harus dilakukan uji asumsi terdahulu. Uji asumsi yang diperlukan untuk menganalisis statistik dengan uji korelasi produk moment menggunakan uji normalitas sebaran dan uji linearitas. Uji normalitas sebaran dilakukan untuk mengetahui varian variabel yang sedang dianalisis akan mengikuti ciri-ciri sebaran normal baku. Sedangkan uji linearitas dilakukan untuk mengetahui ada tidaknya hubungan secara signifikan antara variabel $\mathrm{X}$ dan variabel $\mathrm{Y}$.

Uji normalitas dilakukan terhadap variabel tipe kepribadian dan variabel motivasi berafiliasi. Uji 
normalitas dengan menggunakan SPSS adalah dengan uji KolmogorovSmirnov. Pedoman untuk mengambil keputusan dari hasil uji normalitas dengan uji Kolmogorov-Smirnov (pada kolom uji KolmogorovSmirnov) adalah Jika nilai signifikansilebih besar atau sama dengan (Sig. R 0,05) maka dikatakan normal. Jikanilai signifikansi lebih kecil (Sig. < 0,05) maka dikatakan tidak normal.

Hasil uji normalitas pada variabel tipe kepribadian diperoleh nilai Kolmogorov-Sminov nilai sig.= 0,080, berarti sig. > 0,05 dengan demikian dapat disimpulkan bahwa distribusinya normal.

$\begin{array}{crrr} & \text { Berdasarkan } & \text { hasil korelasi } \\ \text { antara } & \text { Variabel } & \text { Kecerdasan }\end{array}$ emosional dengan Prestasi Kerja menggunakan program SPSS 17.00 for windows dengan tehnik Analisis of Varians diperoleh $\mathrm{F}=100.141$ dengan $\mathrm{p}=0,000$. Jika signifikansi yang diperoleh $<\mathrm{N}$, maka variansi setiap sampel sama (linear) karena signifikansinya $\mathrm{p}<\mathrm{N}=0.05$, maka dapat disimpulkan bahwa antara variabel Kecerdasan emosional dengan Prestasi Kerja terdapat hubungan yang Linear.

Teknik statistik yang digunakan untuk mengetahui adanya hubungan kecerdasan emosional dengan prestasi kerja distributor Multi Level Marketing (MLM) K-Link cabang Sidoarjo menggunakan teknik analisis korelasi product moment pearson. Proses analisisnya dilakukan dengan menggunakan program SPSS-17 For Windouws. Hasil uji korelasi (pearson correlation) diperoleh $=0.689$ serta nilai $\mathrm{p}<0,05(0,000<0,05)$ yang berarti bahwa ada hubungan kecerdasan emosional dengan prestasi kerja distributor Multi Level Marketing (MLM) K-Link.

Berdasarkan nilai Signifikansi, bisa di ambil simpulan atas hipotesis :

- $\mathrm{H} 0=$ Tidak ada hubungan (korelasi) antara dua variabel.

- $\mathrm{H} 1$ = Ada hubungan (korelasi) antara dua variabel.

Dasar pengambilan keputusan
berdasarkan
menggunakan kriteria:

- Jika probabilitas >0,05 (atau 0,01), maka H0 diterima

- Jika probabilitas < 0,05 (atau 0,01), maka H0 ditolak.

Berdasarkan data yang diketahui bahwa nilai probabilitasnya sebesar $0,000 \quad(\mathrm{p}=0.001) \quad$ berarti hipotesa diterima, berarti terdapat hubungan yang signifikan . Dalam penelitian ini diketemukan hubungan yang signifikan antara kecerdasan emosional dengan prestasi kerja $(p<0,05) . P=0.00<0,05$ dengan hasil pearson correlation sebesar 0,689, yang berarti hipotesa diterima.

$\begin{array}{rr}\text { Dalam } & \text { penelitian ini } \\ \text { hubungan } & \text { yang }\end{array}$ signifikan antara kecerdasan emosional dengan prestasi kerja ( $p$ value $<0,05)$. Dengan hasil Product Moment pearson correlation sebesar 0,689 diketahui tingkat hubungan kedua variabel tersebut berada pada level kuat (sugiyono, 2003) yang berarti semakin positif kecerdasan emosional semakin tinggi prestasi kerja.

Pencapaian prestasi kerja yang tinggi pada distributor memiliki 
kecerdasan emosional yaitu individu untuk dapat menggunakan perasaannya secara optimal guna mengenali dirinya sendiri dan lingkungan skitarnya. Dengan kecerdasan emosional ini setiap distributor akan mampu melakukan pekerjaannya dengan baik. Menurut Hasibuan (2001) prestasi kerja adalah suatu hasil kerja yag dicapai seseorang dalam melaksanakan tugastugas yang dibedakan kepadanya yang didasarkan atas kecakapan, pengalaman, dan kesungguhan serta waktu.

Tingkat kecerdasan emosional seorang distributor itu tinggi apabila ia mampu mengelola emosinya dan mampu memotivasi dirinya sendiri. Jika kecerdasan emosional dikaitkan dengan prestasi kerja maka distributor Multi Level Marketing (MLM) dengan kecerdasan emosional tinggi akan lebih mampu membina hubungan dengan orang lain, khususnya pada rekruitmen untuk mendapatkan member baru. Dalam bisnis K-Link yang berbasis MLM kemampuan ini sangat diperlukan untuk memprluas jaringan. Terkait dengan pencapain omset tutup point maka dengan memiliki member yang banyak akan mempermu dah mencapai target point sehingga prestasi kerja akan tercapai.

Seorang distributor yang memiliki kecerdasan emosional yang tinggi maka ia mempunyai prestasi kerja yang tinggi pula. Sedangkan seorang distributor yang mempunyai kecerdasan emosional yang rendah maka dalam prestasi kerjanya akan rendah pula. Dengan demikian terdapat hubungan positif antara kecerdasan emosional dengan prestasi kerja. Penelitian ini menunjukkan untuk meraih prestasi kerja di butuhkan kemampuan kecerdasan emosional.

\section{KESIMPULAN.}

Berdasarkan hasil analisa dan interpretasi data penelitian dapat ditarik kesimpulan mengenai hasil penelitian, bahwa ada hubungan yang signifikan antara kecerdasan emosional dengan prestasi kerja.

\section{DAFTAR PUSTAKA}

Arikunto, Suharsimi. 2006. Prosedur Penelitian(Suatu Pendekatan Praktek)

Edisi Revisi VI. Jakarta: Rineka Cipta.

Anwar, Saifuddin. 1999. Penyusunan Skala Psikologi. Yogyakarta: PustakaPelajar.

Azwar, S. (2008). Penyusunan Skala Psikologi. Yogyakarta: Pustaka Pelajar.

Bungin, Burhan. 2008. Metodologi Penelitian Sosial. Surabaya: AirlanggaUniversity Press.

Cooper, R.K. 1999. Executive EQ: Kecerdasan emosional Dalam Kepemimpinandan Organisasi. Jakarta: PT Gramedia Pustaka Utama.

Darusalam.2010. Hubungan Kecerdasan emosional Dengan Penyesuaian Diri

Mahasiswa Fakultas Psikologi Universitas Muhammadiyah Sidoarjo : Psikologi UM Sidoarjo 
Faktor-faktor kecerdasan emosional. Diakses 12 Januari 2012 darihttp://lapiyu.blogdetik.com.

Goleman, D. 1996. Emotional Intelligence. Alih Bahasa: Hermaya. Jakarta: PTGramedia Pustaka Utama

Goleman, D. 2000. Kecerdasan emosional : Mengapa EI lebih penting daripadaIQ. Terjemahan: Hermaya, T. Jakarta: Gramedia Pustaka Utama.

Goleman, D. 2003. Working with emotional intelligence. Kecerdasan emosi untukmencapai puncak prestasi. Alih bahasa : Alex Tri Kantjono Widodo. Jakarta: PT Gramedia Pustaka Utama.

Ghozali, Imam. 2002. Aplikasi Analisis Multivariate dengan Program SPSS.Badan Penerbit Universitas Diponegoro, Semarang.

Hadi, S. (2000). Metodologi Research. Yogyakarta:Yayasan Penerbit FakultasPsikologi UGM

Harefa, Andreas, Multi Level Marketing Alternatif Karier dan Usaha Menyongsong Milenium Ketiga, Jakarta: PT:Gramedia Pustaka Utama,1999, cet.ke-1.

Hasibuan, M. S. P. ( 2001). Manajemen Sumber Daya Manusia. Jakarta: BumiAksara.

Hasibuan. 2002. Organisasi dan Motivasi. Jakarta : Bumi Aksara.

Mangkunegara, Anwar Prabu A.A.2000. Manjemen Sumber
Daya Manusia Perusahaan. Bandung Rosdakarya

Mathis, Robert L. dan John H. Jackson. 2000. Manajemen Sumber Daya Manusia, Edisi Pertama Salemba Empat, Jakarta

Niswatun,Nisak.2010.Hubungan

Kecerdasan emosional Dengan Kinerja Guru. Sidoarjo: Psikologi UM Sidoarjo

Nasir, Mohammad, 1998, Metode Penelitian, Jakarta : Ghalia Indonesia.

Nawawi, Hadari, 1998, Manajemen Sumber Daya Manusia : Untuk Bisnis Yang

Kompetitif, Yogyakarta : Gajah Mada University Press.

Patton, H. 2001. Emotional Intelligence di Tempat Kerja. Terjemah: ZainiDahlan. Jakarta:Pustaka Delaprasa.

Tumpubolon, $\quad$ Robert.2004.NetPreneur Enterpreneur.Jakarta: PT. GramediaScreat Book Of MLM. 2005.tidak untuk umum

Shapiro, Lawrence E.2001. Mengajarkan Emotional Intelligence pada Anak,penerjemah Alex Tri Kantjono. Jakarta: Gramedia.

Stein, S. J. \& Book, H. E. 2002. Prinsip dasar kecerdasan emosi meraih sukses.Alih bahasa: Januarsari, T, R \& Murtanto, Y. Bandung: Kaifa.

Sugiyono. 2003. Metode Penelitian Administratif. Bandung: Alfabeta. 
Sugiyono. 2009. Metode Penelitian

Kuantitatif, Kualitatif da $R \& D$. Bandung:Alfabeta.

Singarimbun, M. \& Effendi, S. (1995). Metode Penelitian Survai. Jakarta: LP3ES.

Suprihanto. 2006 [12 Januari 2009]. Hubungan Antara Motivasi Kerja denganPrestasi Kerja Karyawan di Jurnal Bogor. Diakses dari www.google.com.Pada tanggal 15 Juni 2012

Warren J keegan, Manajemen pemasarn global, alih bahasa, Alexander sindorodan tanty syalina tarigan ; penyunting bahasa, bob wiyahartonojakarta:Prenhalindo 2003.

Pengertian Multi Level Marketing. Diakses pada tanggal 15 Juni
2012

darihttp://kolokiumkpmipb. wordpress.com

Pandangan Umum Bisnis Multi Level Marketing. Diakses pada tanggal 29 mei 2012 dari http://www.masbied.com

Pengertian Distributor. Diakses pada tanggal 20 Agustus 2012 dari http://en.wikipedia.org/wiki/Dis tribution_(business)

Definisi Distribusi Secara umum. Diakses pada tanggal 23 Agustus 2012 dari www.dikmenum.go.id

Definisi Multi Level Marketing. Diakses pada tanggal 28 Juli 2012

darihttp://id.shvoong.com/busi 